\title{
Privatisasi Menuju BUMN yang Lebih Berorientasi pada Pasar
}

\author{
Edy Suandi Hamid
}

\section{Perkembangan Swastanisasi}

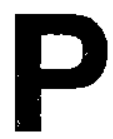

roses swastanisasi atau privatisasi Badan Usaha Milik Negara (BUMN) atau public enterprises sudah gencar berlangsung sejak awal dasawarsa 1980-an. Dasar utama proses privatiasi ini terutama adalah pemikiran bahwa aktivitas ekonomi dan bisnis lebih baik diserahkan kepada swasta, karena usaha yang dikelola swasta umumnya lebih efisien. Dengan penyerahan unit-unit usaha BUMN pada swasta, maka pemerintah dapat lebih mengkonsentrasikan diri dan dananya pada kegiatan-kegiatan untuk menjalankan roda pemerintahan tanpa terlibat banyak pada urusan bisnis. Di samping itu, dengan privatisasi tersebut dianggap juga sebagai langkah lebih mendemokratisasikan ekonomi, karena masyarakat dapat masuk ke semua bidang usaha. Walaupun pemikiran demikian juga banyak ditentang, namun yang terjadi adalah proses privatisasi ini terus menggelinding.

Privatisasi tersebut tidak saja terjadi di negara berkembang, tetapi juga di negara-negara maju seperti Amerika Serikat, Inggris, Kanada, Jepang, Jerman, dan sebagainya. Amerika Serikat, misalnya, be- berapa negara bagiannya menjual PLN-nya, dan menyerahkan urusan pemadam kebakaran pada swasta. Kanada melepas BUMN bidang telekomunikasinya, di samping puluhan BUMN lainnya. Bahkan Kanada menempatkan seorang menteri negara khusus menangani privatisasi tersebut. Inggris, yang diawali oleh PM Margareth Thatcher, juga melakukan hal yang sama, misalnya menjual saham British Telcom dan British Gas di bursa London. Dalam periode pemenintahan Thatcher tersebut (1979-1993), Inggris memperoleh penerimaan sebesar 55 miliar poundsterling dari penjualan BUMN. Jika sebelumnya setiap tahun harus memberi subsidi 3 miliar poundsterling, berbalik menghasilkan tambahan penerimaan pajak 60 juta poundsterling per minggu. Lebih dari itu, pelayanan pun menjadi lebih baik pasca privatisasi, seperti tercermin dari penurunan tarif gas dan telekomunikasinya (Warta Ekonomi, 1997, h. 35).

Di Republik Rakyat Cina (RRC), yang ekonominya dikendalikan oleh negara, tahun 1995 mengumumkan hanya akan mempertahankan 1000 BUMN dari 100 ribu BUMN yang dimilikinya (Bacelius Ruru, 1997). Sunita Kikeri, John Nellis dan Mary Shirley menunjukkan selama kurun waktu 1980- 
1992 terdapat lebih dari 15.000 BUMN di seluruh dunia yang diswastakan (World Bank Research Observer, Juli 1994). Keadaan ini sangat berbeda dengan kondisi tahun 1950-an hingga 1970-an, di mana waktu itu pemerintah sangat aktif dalam perekonomian, dan BUMN dijadikan alat untuk mendukung berbagai program ekonomi pemerintah. Adanya era kesejagatan (globalisasi) ekonomi, yang mengarahkan perilaku ekonomi pada persaingan bebas, telah memaksa setiap pelaku dan unit ekonomi untuk bertindak efisien, sehingga banyak melakukan reformasi dalam kaitan dengan BUMN-nya.

\section{Swastanisasi di Indonesia}

Gagasan swastanisasi tersebut juga muncul di Indonesia tahun 1986 yang dilontarkan oleh seorang pejabat Badan Pemeriksa Keuangan dan Pembangunan (BPKP). Gagasan ini ternyata mendapat respons dari pemerintah yang tercermin dari pembentukan Team Pengkajian Antar Departemen pada tahun 1987 yang dipimpin Menko Ekuin dan Pengawasan Pembangunan (PDBI, 1989). Saat ini sudah keluar Keputusan Presiden No. 55/1966 yang membentuk Tim Privatisasi BUMN. Tim ini sebenarnya hanya menggantikan tim yang pernah dibentuk oleh Menteri Keuangan, yang dibubarkan setelah privatisasi PT Telkom beberapa waktu lalu. Walaupun pemikiran tentang swastanisasi ini mendapat perhatian dari pemerintah, namun dalam prakteknya berjalan lamban. Bahkan Bank Dunia (1996) menilai Indonesia' sebagai negara yang paling lamban dalam melaksanakan proses swastanisasi BUMN di Asia Timur, di samping juga dianggap sebagai yang tidak transparan BUMN-nya.

Proses swastanisasi ini sebenarnya dapat dilihat dari beberapa bentuk. Swastanisasi antara lain bisa dilakukan dengan menjual penuh atau melepas sepenuhnya BUMN kepada perusahaan swasta. Artinya, setelah dijual pemerintah tidak lagi mempunyai hak apa-apa pada BUMN tersebut. Namun demikian, pemerintah selaku pemegang saham bisa melepas sebagian saja sahamnya kepada swasta, baik melalui penawaran umum di pasar modal maupun penempatan modal langsung (direct placement), atau bahkan melalui kombinasi keduanya. Dalam konteks Indonesia, kebijakan dari Depkeu saat ini lebih memprioritaskan pada penjualan saham di bursa efek (go public), sebagaimana yang dilakukan oleh PT Semen Gresik, PT Indosat, PT Telkom, PT Timah, dan Bank BNI (Bacelius Ruru, 1997). Pemilik saham dominan tetap berada di tangan pemerintah.

Walaupun pemerintah tetap mendominasi saham BUMN yang sebagian sudah dijual itu, namun demikian langkah ini tetap akan memberikan dampak positif dalam manajemen BUMN yang acap disebut kurang profesional itu. Dengan penjualan saham itu, maka BUMN menjadi perusahaan publik yang pengelolaannya mau tidak mau harus lebih profesional dengan tingkat keterbukaan (transparansi) yang tinggi. Kontrol yang lebih luas dari para pemegang saham akan membuat eks BUMN lebih berhatihati dalam operasionalnya, dan lebih berorientasi pada perbaikan kinerja perusahaan. Pos-pos pengeluaran yang tidak perlu yang dapat mempertinggi biaya perusahaan, misalnya, dapat lebih dikendalikan. Jadi, budaya yang sebelumnya masih menyisakan budaya birokrat, harus diganti dengan budaya yang berorientasi bisnis, dengan karakteristik yang responsif terhadap perkembangan pasar dan berupaya untuk bertindak agresif, produktif, dan efisien. Di sisi lain, bagi pemerintah ini mengandung konsekuensi pula untuk tidak bisa terlalu jauh campur tangannya dalam manajemen BUMN tersebut. 
Jika melihat perkembangan yang ada, maka privatisasi tampaknya memang mendesak untuk dilakukan atas BUMN di tanah air. Paling tidak ada tiga alasan lain, baik dilihat dari kondisi internal BUMN maupun kondisi eksternal dan global yang ada, untuk melakukan privatisasi atau swastanisasi tersebut. Pertama, "wajah" BUMN di tanah air sebagian masih menampakkan sosok buram yang. mencerminkan kinerja yang tidak baik. Sebagaimana tercermin pada Tabel 1, lebih separo BUMN di tanah air dalam kondisi yang tidak menggembirakan. Kinerja BUMN tersebut terutama dilihat dari aspek rentabilitasnya (kemampuan untuk memperoleh laba), di samping aspek likuditas (kemampuan memenuhi semua kewajiban jangka pendek) dan solvabilitas (kemampuan memenuhi semua kewajiban jangka panjang). Melihat bahwa banyak fasilitas dan proteksi yang diberikan kepada BUMN, maka kinerja yang ditunjukkan tersebut memang cukup memprihatinkan. Karenanya, privatisasi diharapkan akan dapat memperbaiki wajah kusam sebagian BUMN tersebut.

Kedua, perkembangan ekonomi dunia yang makin terbuka dan liberal menuntut setiap unit usaha bertindak profesional dan menekankan kinerja yang berorientasi pada efsiensi. Jadi, pola pengelolaan BUMN haruslah lebih berorientasi kepada pasar, yang cepat tanggap pada situasi dan kondisi ekonomi yang terjadi serta fleksibel, dan bukan pada gaya birokrat yang kaku dan hirarkhis dalam setiap langkah atau pengambilan keputusannya. Campur tangan pemerintah yang terlalu jauh pada manajemen BUMN, dan proteksi yang berlebihan, tak mungkin lagi diterapkan manakala era keterbukaan ekonomi sudah "mengikat" Indonesia untuk mengikutinya secara penuh, sebagaimana komitmen Indonesia dalam AFTA, APEC dan WTO.
Ketiga, kecenderungan demokratisasi dalam aktivitas ekonomi domestik agaknya juga akan lebih menguntungkan bagi pemerintah untuk menanggalkan sebagian usahanya untuk diserahkan kepada swasta. Dengan proses ini maka partisipasi rakyat dalam perekonomian akan lebih luas, khususnya atas sektor yang tak menguasai hajat hidup orang banyak, dan beban pemerintah pun berkurang untuk mengurusi unit usaha yang relatif tidak terlalu penting, karena penanganannya sudah bisa dialihkan ke masyarakat luas. Namun demikian, untuk proses swastanisasi penuh ini, tetap harus selektif dan transparan agar proses swastanisasi tersebut tidak sekedar mentransfer unit usaha monopoli, misalnya, dari pemerintah ke swasta tertentu saja.

Jika dilihat dalam skala makro, produksi dan investasi nasional sudah semakin besar ditangani swasta. Hal ini menggambarkan bahwa badan usaha swasta kian mampu masuk dan menangani berbagai bidang usaha dalam perekonomian nasional. Ini sangat berbeda dengan kondisi masa lalu di mana pemerintah merupakan unit yang paling aktif dan sangat menentukan dalam perekonomian, baik melalui BUMN maupun departemen teknis yang ada. Perkembangan peran swasta ini mengindikasikan pula bahwa tidak akan sulit dunia usaha swasta untuk menerima sebagian usaha yang kini ditangani BUMN.

Melihat perkembangan tersebut, maka privatisasi untuk BUMN kita tak seharusñya dibatasi pada menjual sebagian sahamnya kepada khalayak, melainkan juga bisa secara penuh. Swastanisasi tipe ini memang hanya terbatas pada sektor yang memang diminati swasta dan tidak menyangkut kepentingan rakyat banyak. Misalkan saja pada bidang transportasi udara, di mana paling tidak kini ada 3 BUMN yang ambil bagian. Di sini swasta sudah cukup mampu, sehingga pemerintah bisa melepas 
Topik: Privatisasi Menuju BUMN yang Lebih Berorientasi pada Pasar, Edy Suandi Hamid

dua dari unit usaha itu kepada swasta. Juga unit usaha perhotelan, biro pariwisata/ perjalanan yang ditangani oleh anak perusahaan BUMN, perindustrian, dan sebagainya. Namun demikian untuk unit usaha yang secara teknis masih mampu ditangani oleh BUMN dan dapat memberikan keuntungan pada pemerintah, memang tidak perlu dilepas. Ini mengingat BUMN juga mempunyai misi untuk memperoleh laba guna menambah budget pemerintah. Hanya saja dalam pengelolaannya sesuai dengan prilaku bisnis lainnya, yang siap berkompetisi secara bebas dan hidup tanpa proteksi atau fasilitas berlebihan dari pemerintah. Jadi, walaupun dilihat dari asetnya tetap dimiliki pemerintah, namun dari kaca manajemennya sudah bergaya swasta atau "privatisasi manajemen", yang dikenal pula dengan sebutan "korporatisasi".

\section{Persoalan Misi Non-ekonomi}

Proses swastanisasi di negara kita memang tidak mudah. Ini terkait dengan misi atau karakteristik dari BUMN tersebut. Salah satu karakteristik dari Badan Usaha Milik Negara (BUMN) yang membedakannya dengan badan usaha swasta adalah berkaitan dengan misinya, yang tak hanya bermuatan ekonomi - keuntungan maksimum -, namun juga mempunyai misi sosial: melayani kebutuhan dan kepentingan masyarakat banyak. BUMN acapkali pula disebut sebagai agent of development. Oleh karena itu, demi untuk kepentingan masyarakat banyak, maka bisa jadi BUMN yang mempunyai potensi untuk memperoleh keuntungan berbalik menjadi merugi. Pada masa lalu kita melihat, misalnya, BUMNBUMN seperti PNKA (sekarang Perumka), PN Pos dan Giro (sekarang perum Pos dan Giro), PN DAMRI dan sebagainya, dapat dikatakan selalu merugi. Namun ini selalu ditoleransi karena- sesuai dengan kondisi ekonomi masyarakat waktu itu - perusahaan-perusahaan tersebut terpaksa menjual jasanya di bawah biaya produksi.

Namun sejalan dengan perkembangan ekonomi dan daya beli masyarakat, kini hampir semua BUMN diarahkan untuk memperoleh keuntungan, walaupun tetap menyandang fungsi pelayanan pada masyarakat. Ini tercermin dari perubahan-perubahan status BUMN yang diarahkan kepada persero (dari PN, Perjan dan Perum), walaupun perjalanannya cukup lambat. Dalam tahun 1996, status BUMN yang berupa Persero ini baru 16 buah, dan berstatus Perum 147 buah dan bentuk lainnya 3 buah. Ini menggambarkan bahwa hanya bagian kecil dari BUMN kita yang diarahkan sepenuhnya untuk berorientasi pada maksimalisasi profit tanpa embel-embel pelayanan. Sebagian besar masih dibebani fungsi pelayanan masyarakat, di samping mencari keuntungan. Ini seharusnya dievaluasi kembali apakah status Perum yang demikian banyak tersebut tidak secepatnya untuk diarahkan untuk diubah menjadi Persero.

Dengan status persero mengandung makna BUMN tersebut diorientasikan untuk memperoleh keuntungan atau tidak lagi merugi. Namun demikian kenyataannya, sebagian dari BUMN kinerjanya masih jauh dari yang diharapkan. Sebagian besar masih masuk kategori yang tidak sehat dan kurang sehat. Data tahun 1996 menunjukkan, sebanyak $51,2 \%$ dari 166 BUMN yang ada masuk kategori tidak sehat $(34,33 \%)$ dan kurang sehat $(17,47 \%)$. Jika kita melihat perkembangannya selama tujuh tahun terakhir, tampak bahwa usaha penyehatan ini tidak menunjukkan banyak hasilnya (Tabel 1).

Sebagian kritik menyatakan, di samping masih rendahnya profesionalisme manajemen BUMN, penyebabnya adalah ketidakjelasan misi sosial dan misi ekonomi dari BUMN tersebut. Akibatnya, de- 
Topik: Privatisasi Menuju BUMN yang Lebih Berorientasi pada Pasar, Edy Suandi Hamid

Tabel 1. Perkembangan Kesehatan BUMN 1990-1996

\begin{tabular}{|l|c|c|c|c|c|c|c|}
\hline Kriteria & 1990 & 1991 & 1992 & 1993 & 1994 & 1995 & 1996 \\
\hline Sehat sekali & 56 & 50 & 43 & 43 & 52 & 49 & 44 \\
Sehat & 45 & 44 & 46 & 38 & 33 & 43 & 36 \\
Kurang sehat & 27 & 28 & 39 & 38 & 35 & 37 & 29 \\
Tidak sehat & 57 & 65 & 58 & 64 & 62 & 49 & 57 \\
\hline Jumlah & 187 & 187 & 186 & 183 & 182 & 178 & 166 \\
\hline
\end{tabular}

Sumber: Riset Warta Ekonomi, Oktober 1997

ngan mudah BUMN yang merugi berdalih pada beban-beban non ekonomi ini yang menjadi penyebab BUMN tersebut merugi. Namun demikian, tidak bisa dipungkiri campur tangan eksekutif (pemerintah) selaku pemilik perusahaan terhadap manajemen merupakan salah satu faktor yang menyebabkan buruknya kinerja BUMN di tanah air, termasuk Badan-badan Usaha Milik Daerah (BUMD). Campur tangan ini tidak saja menyangkut perencanaan perusahaan, melainkan juga berkait dengan personalianya. Pertimbangan-pertimbangan non-bisnis tidak jarang justru dominan dalam penentuan manajemen BUMN. Akibatnya, bagi pemegang manajemen BUMN (BUMD) harus sangat berhati-hati dalam berhubungan dengan pemberi mandat ini, yang berakibat tidak luwesnya gerak dari manajemen BUMN.

Masih adanya intervensi pemerintah ini tampak jelas misalnya pada kasus PT Jamsostek. Jajaran direksi, misalnya, harus mengeluarkan dana yang sangat besar untuk mendukung pengesahan Undang-undang Ketenagakerjaan. Adanya perintah dari birokrasi (Menteri Tenaga Kerja) jelas membuat manajemen tidak bisa berbuat apa-apa, kecuali menyetujuinya. Dalam konteks ini kalkulasi bisnis menjadi tidak lagi bisa dipertimbangkan oleh unit BUMN. Campur tangan birokrasi ini tampaknya juga masih terjadi pada perusahaan negara yang sudah go public, seperti pada kasus pergantian direksi PT Telkom dan penggunaan dana untuk pembangunan patung raksasa di Bali. Kasus-kasus kredit macet di bankbank BUMN, yang merupakan tempat kredit macet terbanyak di perbankan Indonesia, disinyalir juga tidak lepas dari adanya campur tangan (oknum) birokrat dalam memperlancar proses penurunan kredit tersebut.

Masih adanya campur tangan yang demikian telah menimbulkan kesangsian bahwa usaha-usaha untuk menyehatkan atau memperbaiki kinerja BUMN akan dapat mewujud sesuai yang diharapkan. Misalnya rencana merger yang dilakukan oleh empat bank BUMN tahun 1998 ini masih ditanggapi skeptis jika intervensi birokrasi masih banyak terjadi. Walaupun sekian banyak manfaat potensial akan diperoleh dari merger, hal tersebut tidak otomatis bank BUMN ini akan menjadi baik kinerjanya. Di samping tergantung pada manajemen baru dari bank BUMN pasca merger, juga sejauh mana campur tangan eksternal (birokrasi) terhadap manajemen bank tersebut. Jika manajemen baru justru lebih buruk, 
dan campur tangan birokrasi masih sering masuk untuk mempengaruhi keputusan profesional dari jajaran manajemennya, maka bukan mustahil hal lebih jelek justru akan terjadi.

Memang dalam kondisi tertentu bisa saja pertimbangan di luar bisnis dinomorduakan. Ini sejalan dengan misi dari BUMN yang juga membawa misi sosial dan sebagai unsur stabilisator perekonomian nasional. Seperti misalnya, pada masa awal krisis moneter beberapa waktu lalu, bank BUMN dijadikan alat oleh pemerintah untuk mengurangi likuiditas rupiah. Kebijakan demikian memang bisa dilakukan BUMN, walaupun sangat mungkin harus mengorbankan keuntungannya, atau bahkan merugi. Tetapi kasus ini adalah kasus yang sangat khusus, dan terkait dengan kepentingan ekonomi nasional. Ini memang sulit dihindarkan. Tindakan yang perlu dihindarkan adalah bentuk campur tangan (atau tekanan) yang membuat keputusan manajemen bank menjadi tidak rasional, misalnya, menyalurkan kredit pada pelaku ekonomi tertentu yang sebetulnya berisiko tinggi pada bank.

Manajemen BUMN Indonesia dewasa ini umumnya masih terbawa mental birokratnya. Padahal gaya dan cara berpikir birokratik jelas tidak akan cocok lagi untuk mengelola unit usaha bisnis yang sekarang semakin ketat persaingannya, dan semakin canggih pula pola manajemennya. Sebagai suatu lembaga bisnis, BUMN benar-benar menuntut tenaga profesional yang ahli dalam bidangnya. Dengan demikian, tidak otomatis seorang yang sudah duduk dan sukses dalam eselon tinggi di birokrasi ataupun di jenjang militer dapat sukses pula dalam memimpin suatu badan usaha.

Dengan kondisi demikian pula tidak mengherankan jika masih terdapat BUMN yang merugi. Tahun 1996 jumlah yang merugi ini masih 20 perusahaan negara. Peru- sahaan yang merugi ini terbanyak di Departemen Perindustrian dan Perdagangan (11 buah), dengan nilai kerugian Rp 182,6 miliar, atau naik lebih $100 \%$ dibanding kerugian tahun sebelumnya yang "hanya" Rp 88,6 miliar. Kondisi demikian tentu memprihatinkan mengingat BUMN tersebut umumnya telah memperoleh berbagai fasilitas dan perlakuan khusus dari pemerintah.

Dalam proses swastanisasi memang tidak bisa diterapkan begitu saja pada semua BUMN. Sebagaimana amanat konstitusional kita, ada cabang-cabang yang memang harus dikuasai oleh negara, seperti yang dianggap menguasai hajat hidup orang banyak. Oleh karena itu, proses swastanisasi ini tetap harus berjalan selektif. Oleh karena itu, perlu ada pengkategorian yang jelas mengenai sektor yang menguasai hajat hidup orang banyak, serta makna penguasaan oleh negara tersebut. Namun demikian, apakah suatu BUMN itu akan diswastakan atau tidak, sebagai suatu perusahaan milik rakyat, maka transparansi dalam pengelolaan perusahaan tersebut harus dilakukan. Pelaporan kinerjanya haruslah secara terbuka, termasuk dalam pelaporan keuangannya. Hal ini justru merupakan hal yang sangat langka bagi BUMN di tanah air. Masyarakat, misalnya, tidak bisa secara terbuka dan jelas mengetahui bagaimana struktur produksi, struktur biaya, dan penerimaan dari suatu BUMN, katakanlah perusahaan seperti PLN, Perumka, ataupun perusahaan-perusahaan air minum yang dikelola oleh Badan Usaha Milik Daerah (Pemda).

\section{Modal asing dan BUMN}

Dengan adanya unit-unit usaha yang go public, maka tidak bisa terhindarkan masuknya modal asing ke dalam BUMN ini. Namun demikian, modal asing ini tidak harus melalui pasar modal, melainkan kerja 
sama langsung dengan BUMN. Formula yang terakhir ini agaknya akan dilakukan pada bank-bank pemerintah yang akan dimerger Juli 1998 ini. Menteri Keuangan, ketika menjelaskan masalah merger bank BUMN ini, mengemukakan rencana untuk memberikan peluang pada pihak asing memiliki saham bank BUMN. Masuknya pihak asing, terlebih yang sudah terkait dengan bisnis perbankan sebelumnya, akan memaksa bank pasca merger untuk secara profesional mengelola banknya. Pihak asing tentu tidak ingin ada campur tangan politik, pengeluaran-pengeluaran tidak rasional, atau langkah-langkah yang dapat merugikan bank tersebut. Di samping itu, masuknya pihak asing akan memberikan peluang lebih besar dalam memperluas jaringan internasional bank-bank BUMN ini.

Mengingat besarnya kekayaan negara yang ada di BUMN perbankan ini, maka memang sewajarnya BUMN perbankan dibawa pada pengelolaan yang profesional dan memberikan keuntungan pada masyarakat luas. Jumlah kekayaan bank-bank BUMN dapat dikatakan tak tertandingi oleh kekayaan BUMN lainnya, kecuali oleh BUMN di Departemen Pertambangan dan Energi. Langkah merger sekarang ini seyogyanya dijadikan titik tolak untuk recovery dalam rangka memposisikan bank-bank BUMN tersebut sebagai bank besar dan sehat tidak saja di tanah air, melainkan juga pada level internasional, paling tidak di Asia Tenggara.

Ada banyak manfaat masuknya modal asing ke BUMN, baik melalui pasar modal maupun penempatan modal langsung, manfaat tersebut antara lain adalah (a) memperbesar modal BUMN. Ini akan menambah dana segar (fresh money) yang akan memudahkan BUMN tersebut melakukan ekspansi, atau menempatkannya menjadi unit usaha yang lebih besar dan diperhitungkan di tingkat internasional; (b) mengurangi be- ban anggaran pemerintah. Dalam keterbatasan anggaran seperti sekarang ini, maka sulit bagi BUMN hanya mengandalkan tambahan penempatan dana dari pemerintah. Saat ini skala prioritas anggaran pemerintah terutama untuk kegiatan rutin, dan pengeluaran pembangunannya. Bahkan karena kesulitan dana ini, untuk pengeluaran pembangunan dalam tahun anggaran 1998/1999 hanya ditargetkan meningkat sekitar $5 \%$, yang mencerminkan betapa sulit dan beratnya alokasi anggaran dewasa ini; (c) akan memaksa BUMN dikelola secara lebih profesional, terbuka, dan lebih fokus pada usaha komersialnya, sehingga menghasilkan barang dan jasa yang efisien dan kompetitif. Ini akan menguntungkan konsumen, di samping pemerintah sendiri yang akan memperoleh lebih banyak keuntungan dari BUMN tersebut, di samping peningkatan penerimaan pajak; (d) akan dapat mendorong kiprah BUMN lebih luas di pasar dunia. Kepemilikan oleh asing, memungkinkan adanya upaya dari pemegang saham tersebut membantu unit usaha ini memperluas pasarnya di tingkat dunia. Umumnya penempatan modal atau pembeli saham asing adalah pemilik dana yang sudah memiliki usaha sejenis atau terkait dengan jenis usaha yang dibeli sahamnya.

Jadi, masuknya modal asing dalam. BUMN tidak perlu terlalu dikhawatirkan. Namun, sebagaimana dikemukakan sebelumnya, masuknya asing dalam BUMN ini bersifat selektif pada unit-unit usaha yang tidak strategis dan tidak terlalu terkait dengan hajat hidup orang banyak tersebut. Sektor pertambangan, perbankan, perhubungan, misalnya, banyak yang bisa ditawarkan ke asing. Misalnya saja perusahaan penerbangan GIA dapat saja dilepas sebagian sahamnya ke asing, mengingat sektor ini tidak menyangkut hajat orang banyak. Di samping itu, dari pengalaman selama ini, perusahaan tersebut selalu rugi 
Topik: Privatisasi Menuju BUMN yang Lebih Berorientasi pada Pasar, Edy Suandi Hamid

dari operasional penerbangannya. Keuntungan yang diperoleh justru dari usahausaha di luar core bisnisnya.

\section{Penutup}

Dari uraian di atas maka dapat disimpulkan adalah mendesak bagi pemerintah untuk melakukan pengkajian atas 166 BUMN yang ada saat ini agar unit-unit usaha tersebut memberikan manfaat yang lebih besar bagi masyarakat. Gambaran yang ada selama ini menunjukkan bahwa kinerja BUMN masih jauh dari yang diharapkan, bahkan sebagian besar masih tergolong kurang sehat dan tidak sehat. Hal ini menuntut pengelolaan BUMN lebih profesional, sejalan dengan tuntutan perkembangan dunia bisnis sekarang ini. Sumberdaya manusia BUMN perlu ditingkatkan kualitasnya, dan dihindarkan dari mental birokrat, yang biasanya dikaitkan dengan karakteristik pekerja yang kurang profesional untuk pengelolaan bisnis, dan kurang responsif atas perkembangan yang ada di pasar.

Salah satu upaya untuk meningkatkan profesionalisme ini adalah melalui privatisasi secara terbatas, yakni menjual sebagaimana saham atau menerima penempatan modal dari swasta, baik asing maupun domestik, sehingga kepemilikan dan kontrol perusahaan menjadi lebih luas, tidak terbatas pada pemerintah saja. Hal ini akan "memaksa" unit usaha yang sahamnya dimiliki pemerintah tersebut lebih terbuka, profesional, dan efisien. Pemegang saham swasta tentu akan selalu menjaga agar perusahaannya tidak merugi, oleh karena itu tuntutan manajemen yang profesional dengan adanya saham swasta itu tidak akan bisa dihindarkan oleh BUMN. Dalam penetapan direksi, misalnya, tak bisa asal tunjuk atau menempatkan petinggi dari departemen tertentu, melainkan harus tenaga profesional yang memahami dunia usaha yang digelutinya. Dalam hal anggaran, maka harus dipisahkan secara ketat antara anggaran departemen dengan BUMN yang sudah melepas sebagian saham ke swasta tersebut. Pemindahan dana dari BUMN ke departemen teknis, misalnya, tidak masuk kategori biaya perusahaan. Dengan demikian tidak terjadi tumpang tindih anggaran, sehingga untung-rugi dari usaha BUMN dapat dievaluasi secara jelas. Namun demikian penjualan saham pada swasta ini tentunya perlu dilakukan secara selektif untuk unit-unit usaha yang menurut konstitusi memang bisa melibatkan swasta untuk menanganinya.

\section{Daftar Pustaka}

Bacelius Ruru, "Privatisasi BUMN Sebagai Strategi Makro di Bidang Pasar Modal", Seminar Pengembangan Pasar Modal, ISEI-PAU Studi Ekonomi UGM, Yogyakarta, 1987.

I Ketut Mardjana, "Korporatisasi dan Privatisasi Sebagai Alternatif Pembenahan BUMN", Jurnal Keuangan dan Moneter, BPEK, Jakarta, 1994.

Kikeri, Sunita et. al. "Privatization: Lesson from Market Economies", World Bank Research Observer, Juli 1994, IBRD, Washington, DC, 1994.

Pusat Data Bisnis Indonesia, Profil dan Anatomi BUMN, edisi kedua, volume 1, 1989, PDBI, Jakarta, 1989.

Warta Ekonomi, Liputan Utama, Warta Ekonomi, No. 23/IX/27 Oktober, 1997, Jakarta, 1997. 